\title{
ANALISIS KESALAHAN EJAAN PADA MAKALAH MAHASISWA STUDI KASUS PRODI ILMU PEMERINTAHAN DAN PRODI ILMU ADMINISTRASI NEGARA STISIP IMAM BONJOL PADANG
}

\author{
GUSNAYETTI \\ Dosen STISIP Imam Bonjol Padang
}

\begin{abstract}
This study aims to describe (1) capital letter errors, (2) errors in writing prepositions and affixes, (4) errors in writing absorption elements, and (4) errors in using punctuation in student papers of Government Science Study Program and Administrative Science Study Program. State of Imam Bonjol Padang State. To deepen and be more focused, the sample of this research amounted to 21 papers consisting of student papers in the Indonesian Language Course of the Government Science Study Program and the State Administration Science Study Program. Data collection was carried out by reading and handicapping techniques, while the data collection instrument used a human instrument, namely the researcher himself. The data analysis technique was carried out with qualitative descriptive analysis techniques. The validity of the data was obtained by means of intrarater and interrater. The results of this study indicate that there are 162 errors in spelling errors in student papers of the Government Science Study Program and State Administration Study Program at Stisip Imam Bonjol Padang consisting of: (1) errors in the use of capital letters as many as 78 errors, (2) errors in writing prepositions in and to 42 errors, which include errors in writing prepositions in as many as 7 errors, errors in writing prepositions into as many as 2 errors, while affixes in as many as 33 errors, and errors in affixes and prepositions of no errors found in student papers, (3) errors the use of punctuation marks as many as 40 errors, which include errors in using period punctuation (.) as many as 37 errors, errors in using colon punctuation (:) as many as 3 errors, and errors in using comma punctuation (,), errors in using hyphens (-). ), errors in using question marks (?), and (4) errors in using exclamation points (!), errors in using comma punctuation marks a (;), errors in using single quotes (tik..."), errors in using quotes ("...”), and errors in using slashes (/) were not found.
\end{abstract}

Keywords: Spelling Mistakes, Papers.

Abstrak: Penelitian ini bertujuan untuk mendeskripsikan (1) kesalahan huruf kapital, (2) kesalahan penulisan kata depan dan imbuhan, (4) kesalahan penulisan unsur serapan, dan (4) kesalahan pemakaian tanda baca pada makalah mahasiswa Prodi Ilmu Pemerintahan dan Prodi Ilmu Administrasi Negara Stisip Imam Bonjol Padang. Untuk memperdalam dan lebih fokus, maka sampel penelitian ini berjumlah 21 makalah yang terdiri dari makalah mahasiswa pada Mata Kuliah Bahasa Indonesia Prodi Ilmu Pemerintahan dan Prodi Ilmu Administrasi Negara. Penggumpulan data dilakukan dengan teknik membaca dan mencacat, sedangkan instrumen pengumpulan data dengan menggunakan human instrument, yaitu peneliti sendiri. Teknik analisis data dilakukan dengan teknik analisis deskriptif kualitatif. Keabsahan data diperoleh dengan cara intrarater dan interrater. Hasil penelitian ini menunjukkan bahwa kesalahan ejaan pada makalah mahasiswa Prodi Ilmu Pemerintahan dan Prodi Administrasi Negara Stisip Imam Bonjol Padang sebanyak 162 kesalahan yang terdiri: (1) kesalahan pemakaian huruf kapital sebanyak 78 kesalahan, (2) kesalahan penulisan kata depan di dan ke sebanyak 42 kesalahan, yang meliputi kesalahan penulisan kata depan $d i$ sebanyak 7 kesalahan, kesalahan penulisan kata depan ke sebanyak 2 
kesalahan, sedangkan imbuhan di-sebanyak 33 kesalahan, dan kesalahan imbuhan keserta kata depan dari tidak ditemukan kesalahan pada makalah mahasiswa, (3) kesalahan pemakaian tanda baca sebanyak 40 kesalahan, yang meliputi kesalahan pemakaian tanda baca titik (.) sebanyak 37 kesalahan, kesalahan pemakaian tanda baca titik dua (:) sebanyak 3 kesalahan, dan kesalahan pemakaian tanda baca koma (,), kesalahan pemakaian tanda hubung (-), kesalahan pemakaian tanda tanya (?), dan (4) kesalahan pemakaian tanda seru (!), kesalahan pemakaian tanda baca titik koma (;), kesalahan pemakaian tanda petik tunggal $\left(, \ldots{ }^{c}\right)$, kesalahan pemakaian tanda petik (“...”), dan kesalahan pemakaian garis miring (/) tidak ditemukan kesalahan.

Kata Kunci: Kesalahan Ejaan, Makalah.

\section{A. Latar Belakang Masalah}

Pada ilmu linguistik atau ilmu bahasa terdapat dua bentuk komunikasi secara mendasar yakni bahasa secara verbal atau nonverbal. Dikatakan bahasa verbal karena dalam penyampaian gagasan atau pendapatpenutur bahasa menggunakan cara tertulis ataupun dengan cara lisan. Sedangkan komunikasi dengan bahasa nonverbal dapat diartikan komunikasi yang tidak menggunakan kata-kata, contohnya bahasa isyarat, simbol- simbol, bahasa tubuh, ekspresi muka dan lain sebagaiya. Berdasarkan hal tersebut pengguna bahasa cenderung menggunakan bahasa verbal karena gagasan, pendapat, ide lebih mudah disampaikanketimbang menggunakan bahasa nonverbal. Meskipun demikian banyak sekali dijumpai kesalahan bahasa yang tidak sesuai dengan aturan ejaan yang berlaku, karena dalam penggunaan bahasa verbal khususnya bahasa tulis, kesalahan-kesalahan tersebut sangat mudah diidentifikasi.

Tentu berdasarkan bukti autentik berupa naskah atau tulisan si penulis. Kesalahan-kesalahanejaan khususnya bahasa tulis cenderung dipengaruhi oleh faktor dari penulis yakni kurang paham mengenai ejaan, kurang terbiasa menggunakan ejaan, maupun faktor lingkungan penulis yang terbiasa menggunakan bahasa yang tidak baku. MenurutPrihantini (2015:104) ejaan adalah keseluruhan peraturan mengenai bagaimana menggambarkan lambang-lambang bunyi-ujaran dan bagaimana interrelasi antara lambang-lambang itu. Hal ini juga didukung oleh pendapat Mustakim (1994: 128) yang mengatakan bahwa ejaan merupakan ketentuanyangmengatur penggunaan huruf menjadi satuan yang lebih besar berikut penggunaan tanda baca. Sedangkan menurut Badudu (1985: 31) menyatakan bahwa ejaan adalah perlambangan fonem dengan huruf. Dalam sistem suatu bahasa ditetapkan bagaimanakah fonem- fonem bahasa itu dilambangkan. Lambang itu dinamakan huruf. Selain itu, perlambangan fonem dengan huruf, dalam sistem ejaan termasuk juga (1) ketetapan tentang bagaimana satu-satuan morfologi seperti kata dasar, kata ulang, kata majemuk, kata berimbuhan, dan partikel-partikel dituliskan, dan (2) ketetapan tentang bagaimana menuliskan kalimat dan bagian- bagian kalimat dengan pemakaian tanda baca seperti titik, koma, titik koma, titik dua, tanda kutip, tanda tanya, dan tanda seru.

Kesalahan-kesalahan ini berdampak pada kualitas sebuah tulisan, karena tulisan yang sempurna isinya belum tentu dikatakan tulisan yang baik, apabila terdapat banyak kesalahan ejaan yang ada didalamnya. Mengenai kesalahan dalam berbahasa, Baradja (1981:12) dalam Turistiani (2013:63), memberikan penjelasan bahwa kesalahan berbahasa adalah terjadinya penyimpangan kaidah dalam tindak berbahasa, baik secara lisanmaupun tertulis.. Penyimpangan itu dibedakan atas kekeliruan (mistake) dan kesalahan (error). Kekeliruan adalah penyimpangan pemakaian bahasa yang terjadi tidak secara sistematis. Kekeliruan mengacu pada language performance yang terjadi karena keterbatasan ingatan, mengeja dalam lafal, keseleo lidah, tekanan 
emosional, dan sebagainya. Sebaliknya, kesalahan adalah penyimpangan dalam pemakaian bahasa yang terjadi secara sistematis. Kesalahan bersifat konsisten dan menggambarkan kemampuan si penulis pada tahap tertentu.

Ejaan Bahasa Indonesia (EBI) menjadi dasar dalam hal tulis menulis, karena EBI merupakan faktor penting dan harus dimengerti oleh seorang penulis. Tujuannya jelas pemakaian EBI membuat apa yang dituliskan menjadi lebih mudah dipahami, dihayati dan dimengerti oleh orang lain (pembaca). EBI merupakan acuan baku dalam tata bahasa Indonesia, dengan EBI sistematika penulisan khususnya rangkaian kalimat atau penulisan karangan menjadi lebih baik dan tepat. Menulis karya ilmiah contohnya, seperti artikel ilmiah, jurnal ilmiah, sekripsi, makalah dan lain sebagainya. Makalah sendiri merupakan karya tulis yang banyak sekali kita jumpai di dunia pendidikan, khususnya di perguruan tinggi. Banyak mahasiswa yang ikut berkontribusi membuat makalah baik untuk tugas maupun bahan presentasi mandiri. Namun, persoalannya banyak ditemukan kesalahan baik dalam sitematika penulisan maupun penyusunan isi khususnya dalam perangkaian kata menjadi suatu kalimat dan kalimat menjadi suatu paragraf. Dalam hal ini, peneliti menemukan berbagai masalah dalam penulisan makalah mahasiswa khususnya pada Prodi Ilmu Pemerintahan dan Prodi Administrasi Negara Stisip Imam Bonjol Padang, hal semacam ini menjadi salah satu bukti bahwa kebanyakan mahasiswa dalam penyusunan makalah masih banyak ditemukan kesalahan dalam hal ejaan terutama segi penulisannya. Padahal mahasiswa hendaknya dituntut dan lebih paham dalam mengaplikasikan ejaan yang benar sesuai dengan kaidah EBI. Karena pada jenjang perguruan tinggi mahasiswa sudah dibekali matapelajaran bahasa Indonesia dari sekolah dasar hingga sekolah menengah atas.

Tujuan penulisan makalah bagi mahasiswa S1 Prodi Ilmu Pemerintahan dan Prodi Ilmu Administrasi Negara yakni melatih ketrampilan menulis yang baik dan benar sesuai dengan kaidah ejaan yang diterapkan pemerintah saat ini, sehingga sebagai calon Sarjana Ilmu Pemerintahan dan Sarjana administrasi Publik dapat memberikan contoh yang baik dalam aspek tulis menulis kepada masyarakat dan tempat bekerja. Selain itu mahasiswa S1 Prodi Ilmu Pemerintahan dan Prodi Administrasi Negara dapat berlatih menyusun skripsi dengan baik dan benar. Karena mahasiswa berlatih untuk terampil menerapkan segala hal yang berkaitan dengan kebahasaan, seperti ejaan, kelas kata, frasa, klausa, kalimat, fonologi, morfologi, sintaksis, dan lain sebagainya. Menurut Ahmadi (2011:52), bahasa yang digunakan dalam makalah merupakan ragam bahasa tulis yang mana berbeda dengan ragam lisan yang masih dibantu oleh sikap tubuh, isyarat, dan mimik penuturnya manakala terjadi perbedaan tanggapan atas pelisanan sesuatu. Bahasa ragam tulis dalam makalah harus jelas, lugas, dan komunikatif supaya pembaca dengan mudah memahami isinya.

Rumusan masalah dalam penelitian ini diantaranya bagaimana bentuk kesalahan pemakaian huruf pada karya tulis mahasiswa khususnya makalah pada Prodi Ilmu Pemerintahan dan Prodi Ilmu Administrasi Negara Stisip Imam Bonjol Padang ? Bagaimana bentuk kesalahan penulisan kata yang terdapat pada karya tulis mahasiswa khususnya makalah pada Prodi Ilmu Pemerintahan dan Prodi Ilmu Administrasi Negara Stisip Imam Bonjol Padang ? Bagaimana

bentuk kesalahan penulisan unsur serapan yang terdapat pada karya tulis mahasiswa khususnya makalah pada Prodi Ilmu Pemerintahan dan Prodi Ilmu Administrasi Negara Stisip Imam Bonjol Padang? Bagaimana bentuk kesalahan penulisan tanda baca yang terdapat pada karya tulis mahasiswa khususnya makalah pada Prodi Ilmu Pemerintahan dan Prodi Ilmu Administrasi Negara Stisip Imam Bonjol Padang? 


\section{B. Metodologi Penelitian}

Penelitian ini dilakukan dengan menggunakan pendekatan kualitatif yang termasuk dalam penelitian kebahasaan. Boydan dan Taylor dalam (Moleong, 2006: 4) mengatakan bahwa pendekatan kualitatif merupakan prosedur penelitian yang menghasilkan data deskriptif berupa kata-kata tertulis atau lisan dari orang-orang dan perilaku yang dapat diamati. Objek penelitian ini adalah ejaan dalam makalah mahasiswa Mata Kuliah Bahasa Indonesia Prodi Ilmu Pemerintahan dan Prodi Ilmu administrasi Negara yang berjumlah 21 makalah. Analisa ejaan tersebut meliputi kesalahan pemakaian huruf kapital, kesalahan penulisan kata depan di,ke dan imbuhan di- dan ke-, penulisan unsur serapan, dan penulisan tanda baca. Data dikumpulkan melalui teknik baca, yaitu membaca makalah yang telah dipilih dengan cermat dan berulang. Selain teknik baca, penulis juga menggunakan teknik catat untuk mencatat kesalahan-kesalahan yang ditemukan dengan bantuan kartu data dan dikategorikan dalam kriteria kesalahan yang telah ditentukan untuk kemudian dianalisis dan dideskripsikan. Taknik catat ini digunakan untuk mengungkapkan suatu permasalahan yang terdapat dalam suatu bacaan atau wacana (Sudaryanto, 1999: 41). Setelah itu data yangterkumpul didokumnetsikan dengan kartu data. Menurut Sugiyono (2013:240) dokumen merupakan catatan peristiwa yang sudah berlalu. Dokumen bisa berbentuk tulisan, gambar,ataukarya-karya monumental dari seorang. Dokumen yang berbentuk tulisan misalnya catatan harian, sejarah kehidupan (life histories), ceritera, biografi, peraturan, kebijakan.Instrumen pengumpulan data menggunakan human instrument yaitu peneliti sendiri. Peneliti sebagai pelaksana yang akan mengumpulkan data, menganalisis, dan sekaligus membuat kesimpulan.

\section{Hasil dan Pembahasan}

Dari hasil analisis diperoleh kesalahan sebanyak 162 kasus kesalahan, meliputi: (1) kesalahan penggunaan huruf kapital berjumlah 78 kesalahan, (2) kesalahan kata depan $d i$ dan $k e$ berjumlah 42 kesalahan, (3) kesalahan pemakaian tanda baca berjumlah 40 kasus kesalahan dan (4) kesalahan penulisan unsur serapan berjumlah 2 kasus kesalahan yag disajikan dalam tabel berikut ini.

Tabel 1. Persentasi Kesalahan Ejaan pada Makalah mahasiswa Prodi Ilmu Pemerintahan Dan Prodi Ilmu Administrasi Negara Stisip Imam Bonjol Padang

\begin{tabular}{|l|l|l|l|}
\hline No. & Aspek Kesalahan Ejaan & Frekuensi & Persentase \\
\hline 1 & Pemakaian Huruf & 78 & $48 \%$ \\
\hline 2 & Penulisa n Kata di dan $k e$ & 42 & $26 \%$ \\
\hline 3 & Penulisan Tanda Baca & 40 & $25 \%$ \\
\hline 4 & Peulisan Unsur Serapan & 2 & $1 \%$ \\
\hline & Jumlah & 162 & $100 \%$ \\
\hline
\end{tabular}

Dari tabel di atas dapat disimpulkan bahwa kesalahan terbesar yaitu terletak pada pemakaian huruf yang berjumlah $48 \%$ dari total kesalahan. Kesalahan dalam pemakaian huruf didominasi oleh kesalahan pemakaian huruf kapital seperti contoh di bawah ini: 1) "Menambah pengetahuan dan pengalaman pembaca, Untuk kedepannya dapat memperbaiki bentuk," (A/KP); dan 2) "Berikut macam-macam kalimatnya: 1. Berdasarkan Isi atau informasi" (A/6) Selain itu, kesalahan ejaan juga ditemukan pada penulisan imbuhan, yang berjumlah 42 kesalahan penulisan imbuhan di-, ke- dan kata depan di, ke dan dari.

Kesalahan ini terdiri atas 7 penulisan kata depan di, 2 kesalahan penulisan kata depan ke. Sedangkan penulisan kesalahan imbuhan di- terdiri atas 33, kesalahan 
imbuhan ke, dan dari tidak ditemukan. Pada penulisan tanda baca, terdapat 41 kesalahan penggunaan tanda baca, meliputi 38 kesalahan tanda baca titik (.), 3 kesalahan tanda baca titik dua (:). Sementara itu, penulis tidak menemukan kesalahan penggunaan tanda baca koma (,), kesalahan penggunaan tanda hubung (-), kesalahan penggunaan tanda tanya (?), kesalahan penggunaan tanda baca seru (!), kesalahan tanda petik tunggal $\left(, \ldots{ }^{e c}\right)$, kesalahan tanda baca titik koma $(;)$, kesalahan penggunaan tanda petik dua (“...”),dan kesalahan penggunaan tanda baca garis miring (/). Penulis juga menemukan kesalahan pada penulisan unsur serapan yang berjumlah 2 kesalahan.

\section{Penutup}

Berdasarkan hasil penelitian menunjukkan bahwa masih ditemukan kesalahan ejaan pada pada makalah mahasiswa Prodi Ilmu Pemerintahan dan Prodi Ilmu Administrasi Negara Stisip Imam Bonjol Padang. Jenis kesalahan ejaan yang sering dilakukan adalah kesalahan pemakaian huruf kapital, kesalahan penulisan kata depan dan imbuhan $d i$-, $k e$ - dan kesalahan penulisan tanda baca titik (.), tanda baca titik dua (:), dan penulisan unsur serapan. Kesalahan pemakaian huruf kapital ditemukan sebanyak 78 kasus kesalahan atau sebesar $48 \%$. Kesalahan penulisan kata depan di, ke dan dari ditemukan sebanyak 42 kasus kesalahan atau sebanyak 26\% dari total kesalahan. Kesalahan penggunaan tanda baca ditemukan sebanyak 40 kasus kesalahan atau sebesar $25 \%$ dari total kesalahan. Sedangkan Kesalahan penulisan unsur serapan terdapat 2 kesalahan. Kesalahan unsur serapan disebabkan oleh penulisan kata-kata yang masih menggunakan bahasa aslinya, sehingga belum memakai unsur serapan sesuai dengan EBI.

\section{Daftar Pustaka}

Ahmadi, dkk. 2011. Strategi Pembelajaran Sekolah Terpadu. Jakarta: Prestasi Pustaka Publisher

Badudu, J.S. 1985. Cakrawala Bahasa Indonesia. Jakarta: Bahasa Indonesia.

Mustakim. 1994. Membina Kemampuan Berbahasa; Panduan ke Arah Kemahiran Berbahasa. Jakarta: Gramedia

Prihantini, Ainia. 2015. Master Bahasa Indonesia; Panduan Tata Bahasa Indonesia Terlengkap. Yogyakarta: PT Bintang Pustaka

Soedartanto. 2001. Metodologi dan Aneka Teknik Analisis Bahasa. Yogyakarta: Duta Wacana University Press.

Sugiyono. 2013. Metode Penelitian Kuantitatif, Kualitatif dan R\&D. Bandung: CV. AlfabetaTarigan. 1988. Pengajaran Analisis Kesalahan Berbahasa. Bandung:

Angkasa Tim Pengembang Bahasa Indonesia 2016. Pedoman Umum Ejaan Bahasa Indonesia. Jakarta: Badan Pengembangan dan Pembinaan Bahasa.

Widjono, H.S. 2007. Bahasa Indonesia; Mata Kuliah Pengembangan Kepribadian di Perguruan Tinggi. Jakarta: PT Grasindo

Woelong Lexy J. 2006. Metodologi Penelitian Kualitatif. Bandung: Rosda. 